\title{
Job Satisfaction and Job Performance of the Sailors in Rapid Action Boat Squadron of Sri Lanka Navy
}

\author{
A.P. Amila Prasanga \\ Lieutenant \\ Rapid Action Boat Squadron \\ Sri Lanka Navy \\ E- mail: sukysln@gmail.com \\ And \\ Aruna S. Gamage \\ Senior Lecturer \\ Department of Human Resource Management \\ University of Sri Jayewardenepura \\ E-mail: gamage_ashantha@yahoo.com
}

\begin{abstract}
This paper aims at empirically investigating job satisfaction on job performance of the sailors in Rapid Action Boat Squadron in Sri Lanka Navy. Data were collected from 219 sailors using Minnesota Satisfaction Questionnaire (MSQ) and the structured questionnaire developed by Udayakumar (2003) was used for measuring job performance. Pearson Correlation Coefficient and Curve Fit Analysis were employed for the analysis of data. The study substantiated that there is a fairly positive relationship between job satisfaction and job performance of the sailors. The results suggest that the satisfaction aspect on its own does necessarily lead to improved individual performance and assumedly organizational effectiveness. Therefore, it needs to implement satisfaction-performance model effectively through specific practices. The paper empirically investigated satisfaction-performance model in Rapid Action Boat Squadron of Sri Lanka Navy context and offers practical implications for top level administration of the Squadron seeking effective implementation of the satisfaction-performance model.
\end{abstract}

Key Word(s) : Job Satisfaction, Job Performance, Rapid Action Boat Squadron of Sri Lanka Navy

\section{Introduction}

As one of the two elite forces of Sri Lanka Navy, Rapid Action Boat Squadron personnel are trained to a high standard with sufficient level of physical and mental fitness and the capacity to develop their skills. However, there is a continuing problem of attrition and dissatisfaction rate at early stage in sailors' career. In addition to this problem, first it lowers the return on investment in training personnel. Second, high attrition both at the early stage of their naval career has implications for operational effectiveness which reduces the training effectiveness of the Squadron. In combination, these problems will continue to have an impact on retention in the Sri Lanka Navy. Among other factors which could influence on the job performance, job satisfaction (Robbins, 2003; Luthans, 1992; Mitchell and Larson, 1987; Locke, 1976) may be major root to determine the degree of sailor's effort for the Sri Lanka Navy. Current awful nature of human utilization in organizational context may be the basis of sailors' performance as a major factor or as a minor factor. Therefore, the authors try to find out the 
impact of job satisfaction on determining the job performance of the sailors in Rapid Action Boat Squadron of Sri Lanka Navy.

\section{Literature Review and Hypothesis Development}

Job performance has been distinguished as a single most all-encompassing outcome variable in the micro organizational behaviour research (Staw, 1984). The job performance for any one in any milieu is determined by many and different factors. In the Porter - Lawler extension of expectancy theory, the effort (the factors of values of reward, perceived effortrewarded probability), abilities and traits and role perception determine the performance (Moorhead and Griffen, 1999). The equity theory for employee performance determines people from perception of equity or inequity by comparing what they give to the organization relative to what they get back and how this ratio compares with those of others (Moorhead and Griffen, 1999). Vroom (1964), Porter and Lawler (1964), Hellriegel, Slocum and Woodman, (1992), and DeCenzo and Robbins (1993), pointed out that the performance is determined by the level and interaction between ability and motivation.

Gellerman (1963) said that conscious goal setting is an important determinant of levels of performance. Latham and Yukl in 1975 indicated that goal - setting programs improve performance at managerial and non - managerial levels over an expanded period of time in a variety of organization (Gordon, 1993). Locke, Frederick, Buckner, and Bobko based on their research, has suggested that performance was a function of employees' ability, acceptance of goals, level of the goals and the interaction of the goal with their ability (Gordon, 1993).

Kane and Lawler (1978) argued that organizational characteristics (like high formalization, high centralization, and big size are believed to have different effects on employees' attitudes and behavior than low formalization and loosely coupled organizations) and structures influence employees' performance. Herman, Dunham and Hulin (1975) argued that employees who held parallel positions and ranks in the organizational structure reported similar satisfaction with the work and pay, experienced the same level of motivation, and agreed on contingencies for interpersonal behaviour; and employees at the same level agreed in their description of their supervision. Further Herman, Dunham and Hulin (1975) concluded the following: If organizational-structure characteristics are more highly related to organizational behaviour than are demographic characteristics in a variety of different organizational settings, then the effect must be related to employees' ability and willingness to adapt to their work environments. According to Liao, Arvey and Butler (2001), there has been recent research that has shown relationships between personality and job performance in fire fighters.

Considering job performance - job satisfaction relationship, research linking job performance with satisfaction and other attitudes has been studied since at least 1939, with the Hawthorne studies. Some researchers studied the relationship between different job satisfaction aspects and propensity to leave the job (Parasuraman and Futrell, 1983). According to Rao, satisfied employees increase the chances of high productivity (Rao, 2000). Common sense suggests that job satisfaction results in high productivity (Jain and Triandis, 1990).

Schwab and Cummings (1970) identified three major theoretical approaches utilized by the students of the organizations in the study of the relationship between job satisfaction and job performance:

(1) Satisfaction causes performance,

(2) Performance causes satisfaction, and

(3) The relationship between performance and satisfaction is moderated by a number of other variables. 
The job satisfaction leads to job performance is first approach. Job satisfaction is the extent to which a job provides positively value to the job holder. Application of the exchange theory by Organ (1977) suggested a reconsideration of the logic underlying the satisfaction-causesperformance notion. The moderator approach assumes that satisfaction-performance is related under certain circumstances. This approach is attributed by Lawler and Porter's in 1967 work, which emphasized the effects of moderator variables such as rewards contingency and perceived equity of rewards to the relationship between performance and satisfaction.

The second argument of job satisfaction and job performance is that the job performance leads to job satisfaction. The performance causes satisfaction approach is based on the assumption that satisfaction is a function of performance. But the relationship between job performance and job satisfaction has been one of the most controversial issues, which have evolved from decades of research on employee attitudes (Petty, Mcgee and Cavender, 1984).

Another model states that the relationship is a personality and or reciprocal one. This has been supported by the researcher of Wanous (1974). The underlying theory of this reciprocal model is that if the satisfaction is extrinsic then satisfaction leads to performance, but if the satisfaction is intrinsic, then the performance leads to satisfaction. Other models suggest there is either an outside factor that causes a seemingly relationship between the factors or that there is no relationship at all, however, neither of these models have much research. Both extrinsic and intrinsic rewards are indirectly related to job satisfaction and moderated by expected equitable rewards, which refer to the amount of rewards that a person feels he should receive as a result of his job performance.

Job characteristics or the attributes of the employee's work are important variables to consider as they provide the situational perspective within which the employee makes judgment about his or her satisfaction. Job satisfaction or dissatisfaction directly affects employee turnover and absenteeism (Moorhead and Griffin, 1999: Robbins, 2003). Several summaries of the job satisfaction and job performance literature, from both an empirical perspective (Brayfield and Croket in 1955, Vroom in 1964 and a theoretical orientation (Shwab and Cummings, 1970) attempted to recognize the inconsistencies among individual studies resulted by concluding that there is no pervasive relation between workers' job satisfaction and performance. Job performance is a multi - dimensional concept and behaves in different ways on different scenarios. Cox and Nkomo in 1986 pointed out three dimensions for the variable of job performance, which are performance traits, task performance, and social behaviour. Robbins in 2003 said that individual task outputs, behaviour, and traits are the dimensions of job performance. Opatha in 2002 pointed out that the traits, behaviour and results are the dimensions of job performance of an employee. For the purpose of this study, the job performance of the sailors in Rapid Action Boat Squadron of Sri Lanka Navy was defined in terms of tasks, behaviours and traits performance. Therefore, this job performance was measured by the perception of the sailor himself.

Job satisfaction is a nebulous concept. According to Robbins (2003), job satisfaction is a general attitude toward one's job; the difference between the amount of reward workers received and the amount they believe they should receive. "Satisfaction" means the degree of pleasure a person feels by fulfilling his needs (Oxford Dictionary, 1999). Job satisfaction or dissatisfaction is an individual's attitude towards his or her job (Moorhead and Griffin, 1999). Job satisfaction is the sum of an individual's attitudes and feelings about his or her job (Tracey, 1991). Locke in 1976 defines the term of job satisfaction as the degree of favourableness with which an employee views his or her work. Employee satisfaction is the 
degree of pleasure a worker feels by fulfilling his needs in relation to employment (Gupta, 1997). Smith et al. (1969) defined job satisfaction as "feelings or effective responses to facets of the satisfaction". Job satisfaction is a positive orientation of an individual towards the work role, which he is presently occupying. This can be easily paraphrased as an individual liking more aspects of his work than the dislikes. For the purpose of this research, the job satisfaction of the sailors in Rapid Action Boat Squadron of Sri Lanka Navy was defined as a pleasurable or positive emotional state resulting from the appraisal of one's job or job experience (Locke, 1976).

According to Robbins in 2003, Rao in 1999, Jain and Trendis in 1990, Parasuraman and Furtell in 1983, Steers in 1981, Abedel Halim in 1980, Organ in 1977, Lawler and Porter in 1967, Vroom in 1964, Brayfeild and Crokett in 1955 etc., there is positive relationship between job satisfaction and job performance. Based on above evidence, it is hypothesized that the job satisfaction of the sailors in RABS of SLN has a positive relationship with their job performance. Figure 1 shows the schematic diagram of the theoretical framework.

Hypothesis: There is a significant relationship between job satisfaction and job performance of the sailors in RABS of SLN.

Figure: 1 Schematic Diagram of Research Framework

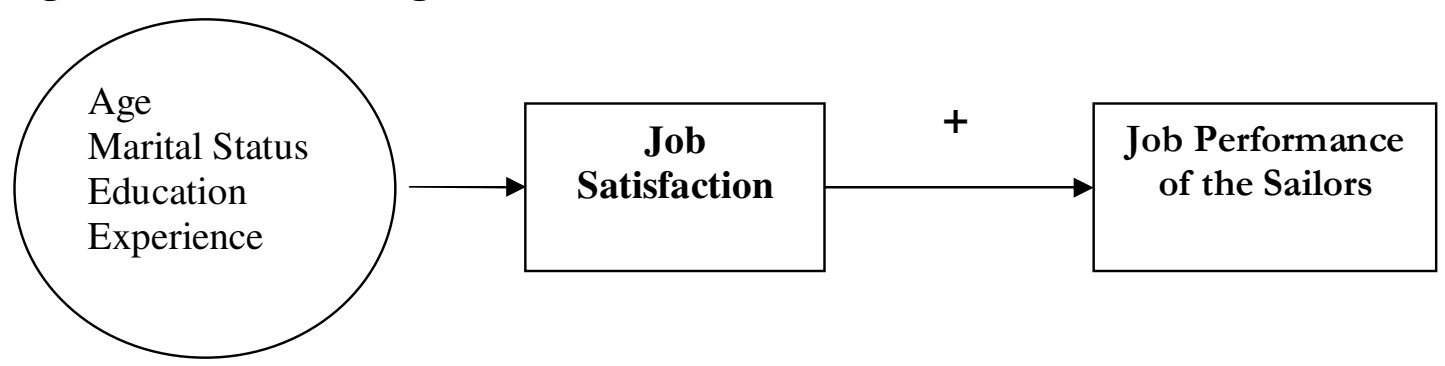

Method

The survey was carried out among the sample of 219 sailors in Rapid Action Boat Squadron of Sri Lanka Navy. The unit of analysis was at individual level (sailor). The selection of sample was carried out on a random sampling method. To collect the primary data required for the study a set of questionnaire was distributed among them. This questionnaire consisted of 44 question statements. All question statements were designed with 5-point Likert scale to measure the variables and dimensions in the research model. The secondary data were collected from the sources such as reports, records, and other publications from various sources. Data collected from primary (questionnaire) source were collected and analyzed using the computer based statistical data analysis package, SPSS version 16.0. The data analysis included the univariate (descriptive) and bivariate analyses. Research conclusions were made based on the results there of.

The reliability of the two instruments used to collect data was examined by using Cornbach's Alpha coefficient. The Cornbach's Alpha coefficient of job performance was 0.866 and job satisfaction was 0.869 . Hence the coefficients of the Cornbach's Alpha indicate that each of the instruments which were used to measure the two variables under the study had sufficient internal reliability. 


\section{Univariate Analysis}

Under the univariate analysis frequency distribution analysis was carried out of respondents by their personal characteristics. The age of the respondents grouped into four levels ranging from 20 to 40 years. The majority $49.3 \%$ of the respondents was within the age group of 2025 and $33.3 \%$ of the respondents were within the age group of 26-30 and $16.9 \%$ of the respondents were within the age group between 31-35 years. Just $0.5 \%$ of the respondents represented the age group 36-40. The majority of the respondents $(56.2 \%)$ were unmarried. The level of education of the majority of the sample (93.2\%) was GCE O/L. This is because GCE O/L is a prerequisite for recruiting the Sri Lanka Navy. The experience levels ranged from 01 to 20 years of the sample. The results show that $45 \%$ of the respondents were 01-05 years' experience in Navy and just 5\% marked over 16 years' experience in their service period.

The frequency distribution analysis was made individually for the variables of job performance and job satisfaction. Frequency distribution analysis results have been interpreted mainly considering the Mean and Compare Mean values. The mean value of the distribution of job performance is 4.4027 . Then the job performance of the respondents is good. The mean value of the distribution of job satisfaction is 2.8776 . Then the respondents are dissatisfied with their job, but reached to marginally satisfied level. Comparison of mean values indicated that there were no differences on either job performance or job satisfaction by any of the considered demographic variables such as age, marital status, education and experience.

\section{Bivariate Analysis}

Bivariate analysis includes the correlation analysis and curve fit analysis which were used to investigate any relationship between independent variable (job satisfaction) and job performance (dependent variable). The correlation analysis was made to investigate any relationship between job performance and job satisfaction. Person Correlation between these two variables is 0.528 which is positive. The statistical evidence claimed that job performance and job satisfaction are positively correlated to each other.

Regression equation of job satisfaction is:

Job Performance $=3.106+\mathbf{0 . 4 5 1}($ Job Satisfaction $)$

The $b$ value of equation, the gradient of the regression, is 0.451 , which is significant at $1 \%$ (0.000). When considered the adjusted $\mathrm{R}^{2}, 27.6 \%$ of the variance of job performance is explained by job satisfaction with the standardized beta 0.528. The ANOVA of the model for Job Performance and Job Satisfaction showed the F value that is 83.992 , which is significant at $1 \%(0.000)$ suggesting that job satisfaction has significantly explained $27.6 \%$ of the variance of job performance. Curve fit for job performance and job satisfaction further confirms the positive linear relationship between job satisfaction and job performance of the sailors in Rapid Action Boat Squadron of Sri Lanka Navy.

According to the results of the tests, the hypothesis is accepted since $r>0$, and $b>0$. Hence the data support the hypothesis that there is a significant positive relationship between job satisfaction and job performance of the sailors in Rapid Action Boat Squadron of Sri Lanka Navy. Further, it has showed a positive relationship.

\section{Discussion of Findings}

It was found that there is a positive relationship between job satisfaction and job performance. According to the result of regression analysis, job satisfaction was found to 
have a positive impact on job performance with the strength of $b$ value of 0.451 . Hence, job satisfaction was found to be a significant predictor of job performance of the sailors in Rapid Action Boat Squadron of Sri Lanka Navy. Discussing the level of job satisfaction of the respondents in the sample it was found that there is a level of job satisfaction with the mean value of 2.8776 and standard deviation of 0.49557 . Accordingly, it was found that the sailors of Rapid Action Boat Squadron were not satisfied with their job; but closet to marginal satisfaction.

The findings of correlation and regression analyses empirically confirmed the arguments given by Schwab and Cummings (1970), Mitchell and Larson (1987). They argued that job satisfaction is one of the most important factors in determining job performance, and it leads to increased job performance. The findings are not matched with the theoretical arguments given by Vroom (1964), Brayfied, and Crockett (1955). Vroom (1964) and Brayfied and Crockett (1955) argue that though people are satisfied they need not necessarily give a high outcome to the organization.

\section{Conclusion}

The problem of the research was to empirically investigate the impact of the job satisfaction on job performance of the sailors in Rapid Action Boat Squadron of Sri Lanka Navy. Based on the theoretical information, conceptual framework was developed to test the relationship of job performance with job satisfaction. According to the findings, it is substantiated that there is a significant positive relationship between job satisfaction and job performance of the sailors in Rapid Action Boat Squadron of Sri Lanka Navy. It was possible for the independent variable to account for $28 \%$ of the variation in job performance while the $72 \%$ of the variation was unexplained by the variable under the study. In fact other variables, which were not considered in this study, should be the variables that may account for the unexplained variables in job performance.

Rapid Action Boat Squadron is one of the two elite forces of Sri Lanka Navy, which established for the purpose of countering the LTTE military strategies. This voluntarily joint special force was trained in highly tough and structured war oriented background. In the sense, the characteristics such as mental and physical capacity, high determination power and enthusiasm keep sailors' job in marginally satisfied level and it leads to high level of job performance. As a major way of enhancing the job performance of the sailors, the programmes relating to the enhancement of the job satisfaction of the sailors in Rapid Action Boat Squadron are to be implemented successfully. Pay (Moorhead and Griffin in 1999), promotion opportunities (Moorhead and Griffin in 1999), work itself ( Moorhead and Griffin, 1999), mentally challenging work (Locke, 1976), equitable rewards (Locke, 1976), supportive working conditions (Locke, 1976), policies and procedures (Moorhead and Griffin, 1999) coworkers (Locke, 1976: Moorhead and Griffin, 1999), and supervisors (Moorhead and Griffin, 1999) needs (Moorhead and Griffin, 1999), aspirations (Moorhead and Griffin, 1999), and institutional benefits (Moorhead and Griffin, 1999) are the some aspects or elements to be considered for upgrading the job satisfaction of a sailor. The decision making top level administration of the organization should consider these aspects and enhance the job satisfaction of the sailors in Rapid Action Boat Squadron to gain maximum contribution to achieve the organizational objectives.

The authors believe the important independent variables that may account for the unexplained variables in the job performance of the sailors may be variables such as mental and physical ability, person energy level, personality dimensions (dependability, self - confidence), 
(Gordon, 1993), group norms, organizational culture, career commitment, job involvement, task environment, turnover intentions, living environment, welfare measures, career development and personal knowledge. Further research studies are suggested to carry out to find the effects of these factors on job performance of the sailors in Rapid Action Boat Squadron of Sri Lanka Navy. This study has been narrowed down with single branch of Sri Lanka Navy. However, it is also useful to extend the research to other branches of Sri Lanka Navy.

\section{References:}

Abedel-Halim, A. A. (1980), Effects of Higher Order need Strength on the Job PerformanceJob Satisfaction Relationship, Personnel Psychology, Vol. 33, pp 335 - 347.

Armstrong, M. (1996), Personnel Management Practice, $6^{\text {th }}$ ed, London: Kogan Page Limited.

Brayfield, A. H., and Crockett, W. H. (1955), Employee Attitudes and Employee Performance, Psychological Bulletin, Vol 52, pp 396-424.

Campbell, J.P. and Pritchart, R.D. (1976), Motivation Theory in Industrial and Organizational Psycho logy, in M.D. Dunnette (ed), Handbook of industrial and organizational psychology, Chicago: Rand McNally.

Cox, Jr. T. and Nkomo, S.M. (1986), Differential Performance Appraisal Criteria: A field Study of Black and white Managers, Group \& Organizations Studies, Vol 11, No 12, pp 101-119.

DeCenzo, D. A. and Robbins, S. P. (1993), Personnel/Human Resource Management. $3^{\text {rd }}$ ed, New Delhi: Pentice Hall of India.

Erez, M., and Zidon, I. (1984), Effect of Goal Acceptance on the Relationship of Goal Difficulty to Performance, Journal of Applied Psychology, Vol. 69, pp 69 - 78.

Field, A. (2000), Discovering Statistics using SPPS for Windows, New Delhi: SAGE Publication

Fisher, C.D. (1980), On the Dubious Wisdom of Expecting Job Satisfaction to Correlate with Performance. Academy of Management Review, Vol. 5, pp. 607-612.

Gellerman, S.W. (1963), Motivation and Productivity. New York: American Management Association.

Gordan, Erica. (1993), The Agony of Forgetfulness. Journal of Nutrition Health Review (IWHR).

Gupta, K.C. (1987), Human Resource Development in Organizations: Concepts and Mechanism, in Batia,B.S, Verma,H.L. and Gary M.C.(ed.) Studies in Human resources Development-01: Understanding HRD: Basic Concepts, New Delhi: Deep $\&$ Deep Publications.

Hellriegal, D, Slocum ,Jr, John W., and Woodman, R. W. (1992), Organizational Behaviour, $7^{\text {th }}$ Ed., St. Paul: West Publishing Company.

Iaffaldano, M.T. and Muchinsky, P.M. (1985), Job Satisfaction and Job Performance: A Meta-Analysis, Psychological Bulletin, Vol. 97, pp $251-273$.

Jacobs, R. and Solomon, T. (1977), Strategies for Enhancing the Prediction of Job Performance from Job Satisfaction, Journal of Applied Psychology, Vol. 62,pp. 417421.

Jain, R.K. and Triandis, H.C. (1990), Management of Research and Development Organizations: Managing the Unmanageable, New York: John Wiley \& Sons.

Judge, T. A., Thoresen, C. J., Bono, J. E., and Patton, G. K. (2001), The Job Satisfaction-Job Performance Relationship: A Qualitative and Quantitative Review, Psychological Bulletin, Vol.127, pp.376-407. 
Kane, J. S., and Lawler, E. E.III., (1978), Methods of Peer Assessment, Psychological Bulletin, Vol.85, pp. 553-586.

Kumara, K.H. H. (2005), Impact of Job Satisfaction, Organizational Commitment, Job Involvement, Occupational Stress and HRM Competencies on Job Performance of HR managers in Apparel Industry in Sri Lanka, Unpublished MBA Thesis, University of Rajarata.

Latham, G.P. and Yukl, G.A. (1975), A Review of Research on the Application of Goal Setting in Organizations, Academic of Management Journal, Vol. 18, pp $824-845$.

Lawler, E. E., III and Porter, L. W. (1967), The Effects of Performance on Job Satisfaction, Industrial Relations, Vol. 7, pp. 20-28.

Liao, H., Arvey, R. D., and Butler, R. J. (2001), Correlates of Work Injury Frequency and Duration among Firefighters, Journal of Occupational Health Psychology, Vol.6, pp. 229-242.

Locke, E.A. (1976), The Nature and Causes of Job Satisfaction, Edited by M.D.Dunnette, Handbook of Industrial and Organizational Psychology, Chicago: McNally.

Locke, E.A., Frederick, E., Buckner, E., and Bobko, P. (1984), Effect of Previously Assigned Goals on self - set Goals and Performance, Journal of Applied Psychology, Vol. 69, pp $694-699$.

Luthans, F. (1992), Organizational Behaviour, Singapore: McGraw - Hill book Co.

Mitchel, T.R., and Larson, J.R, jr. (1987), People in Organization, Singapore: McGraw - Hill International Inc.

Moorhead, G., and Griffin, R.W. (1999), Organizational Behaviour: Managing People and Organization, $3^{\text {rd }}$ ed, Mumbai: Jaico Publishing House.

Opatha, H.H.D.N.P. (2003), Research Methods for Human Resource Management: Questions and Answers. Part 1, Sri Lanka, Author publication.

Organ, D.W. (1977), A Reappraisal and Reinterpretation of Satisfaction Causes Performance Hypothesis, Academy of Management Review, Vol. 2, pp. 46-53.

Oxford Dictionary. (1999), Oxford University Press.

Parasuraman, A., and Futrell, M. C. (1983), Demographics, Job satisfaction, and Propensity to Leave of Industrial Salesman, Journal of Business Research, Vol.11, pp.33-48.

Petty, M.M., Mcgee, G. W., Gail, D. E., and Cavender, J. W. (1984), A Meta-analysis of the Relationships between Individual Job Satisfaction and Individual Performance, Academy of Management Review, Vol. 9, No. 4, pp.712-721.

Porter, L. W., and Lawler E.E.111. (1964), The Effects of Tall vs. Flat Organization Structures on Managerial Job Satisfaction, Personnel Psychology, Vol. 17, pp. 135 148.

Rao, T.V. (2000), HRD Audit, Evaluating the Human Resource Function for Business Improvement, New Delhi: Response book.

Robbins, P. S. (2003), Organizational Behaviour: Concepts, Controversies, and Applications, 5th Ed., London: Prentice Hall International, Inc.,

Schwab, D. P. and Cummings, L. L. (1970), Theories of Performance and Satisfaction: A review, Industrial Relations, Vol.9, pp. 408-430.

Sekaran, U. (1992), Research Method for Business: A Skill Building Approach, $3^{\text {rd }}$ Ed, New York: Hohn Wiley \& Sons, Inc.

Smith, P., Kendall, L., and Hulun, C., (1969), The Measurement of Satisfaction of work and Retirement, Chicago: Rand

Staw, B.M. (1984), Organizational Behaviour: A Review and Formulation of the Field's Outcome Variables. Annual Review of Psychology, No 35, pp. 627 - 666.

Steers, R. M. (1981), Introduction to Organizational Behaviour, Glenview, IL: Scott Foresman. 
Tracey, W. R. (1991), The Human Resources Glossary: A Complete Desk Reference for HR Professionals, New York: American Management Association.

Umstot, D. D. (1984), Understanding Organizational Behaviour: Concepts and Applications, St.Paul: West Publishing Co.

Uthayakumar, R. (2003), An empirical study on the job attitudinal factors influencing the job performance of non-academic employees in the universities in the Eastern Province of Sri Lanka, Unpublished MSc Thesis, University of Sri Jayewardenepura.

Vroom, V. H. (1964), Work and Motivation, New York: Wiley.

Wanous, J. P. (1974), A Causal-Correlation analysis of the Job Satisfaction and Performance Relationship, Journal of Applied Psychology, Vol.59, pp.139-144. 